\title{
Cost-Effectiveness of Device-Aided Therapies in Parkinson's Disease: A Structured Review
}

\author{
Katarzyna Smilowska a,b,1,*, Daniel J. van Wamelen ${ }^{\mathrm{b}, \mathrm{c}, \mathrm{d}, 1}$, Tomasz Pietrzykowski ${ }^{\mathrm{e}}$, \\ Alexander Calvano ${ }^{\mathrm{c}, \mathrm{d}}$, Carmen Rodriguez-Blazquez ${ }^{\mathrm{f}}$, Pablo Martinez-Martin ${ }^{\mathrm{f}}$, \\ Per Odin ${ }^{\mathrm{g}}$ and K. Ray Chaudhuri ${ }^{\mathrm{c}, \mathrm{d}}$ \\ ${ }^{a}$ Silesian Center of Neurology, Katowice, Poland \\ ${ }^{\mathrm{b}}$ Radboud University Medical Center, Donders Institute for Brain, Cognition and Behaviour, Department \\ of Neurology, Centre of Expertise for Parkinson \& Movement Disorders, Nijmegen, the Netherlands \\ ${ }^{\mathrm{c}}$ Institute of Psychiatry, Psychology \& Neuroscience, Department of Basic \& Clinical Neuroscience, \\ King's College London, London, United Kingdom \\ 'Parkinson's Foundation Centre of Excellence at King's College Hospital NHS Foundation Trust, \\ London, United Kingdom \\ ${ }^{\mathrm{e}}$ Research Center for Public Policy and Regulatory Governance, Faculty of Law and Administration, \\ University of Silesia, Katowice, Poland \\ ${ }_{\mathrm{f}}^{\mathrm{f}}$ National Center of Epidemiology and Center for Networked Biomedical Research in Neurodegenerative \\ Diseases (CIBERNED), Carlos III Institute of Health, Madrid, Spain \\ $\mathrm{g}$ University of Lund, Faculty of Medicine, Lund, Sweden
}

Accepted 3 December 2020

Pre-press 27 December 2020

\begin{abstract}
.
Background: Despite optimal dopaminergic treatment most patients in moderate to advanced stages of Parkinson's disease (PD) experience progressively increasing disabilities, necessitating a shift from oral medication to device-aided therapies, including deep brain stimulation (DBS), intrajejunal levodopa-carbidopa infusion (IJLI), and continuous subcutaneous apomorphine infusion (CSAI). However, these therapies are costly, limiting their implementation.

Objectives: To perform a systematic review on cost-effectiveness analyses for device-aided therapies in PD.

Methods: References were identified by performing a systematic search in the PubMed and Web of Science databases in accordance with the PRISMA statement. In the absence of universal cost-effectiveness definitions, the gross domestic product per capita (GDP) in the country where a study was performed was used as a cut-off for cost-effectiveness based on cost per quality adjusted life year (QALY) gained.

Results: In total 30 studies were retrieved. All device-aided therapies improved quality of life compared to best medical treatment, with improvements in QALYs between 0.88 and 1.26 in the studies with long temporal horizons. For DBS, nearly all studies showed that cost per QALY was below the GDP threshold. For infusion therapies only three studies showed a cost per QALY below this threshold, with several studies with long temporal horizons showing costs below or near the GDP threshold.
\end{abstract}

\footnotetext{
${ }^{1}$ These authors contributed equally to this work.

*Correspondence to: Katarzyna Smilowska, MD, PhD, Silesian Center of Neurology, Czerwińskiego 10, 40-123 Katowice, Poland.
} 
Conclusion: Of the device-aided therapies, DBS can be considered cost-effective, but the majority of infusion therapy studies showed that these were less cost-effective. However, long-term use of the infusion therapies appears to improve their cost-effectiveness and in addition, several strategies are underway to reduce these high costs.

Keywords: Parkinson's disease, cost-effectiveness, deep brain stimulation, quality adjusted life year, levodopa-carbidopa intestinal gel, continuous subcutaneous apomorphine infusion

\section{INTRODUCTION}

Parkinson's disease (PD) is a progressive neurodegenerative disease, mostly affecting older people, with a clear impact on quality of life [1]. In the early stages the disease can be managed well with oral therapies at a relatively low cost, but as the disease progresses into more advanced stages, the effect of these therapies diminishes and associated costs of treatment increase. The impact on societal burden of advanced PD may be considerable as the top $20 \%$ of patients incurring most costs, often those in advanced stages of the disease, are responsible for $70 \%$ of secondary care costs associated with the disease $(£ 16,500(€ 22,493)$ per patient per year in the UK) [2]. As the incidence of PD is rising sharply, with a continuous growth in prevalence that is expected to double within the next 25 years [3], costs associated with treatment and the burden this places on society is becoming increasingly relevant.

Oral dopaminergic treatment is effective for alleviating the early symptoms of PD. However, despite optimal dopaminergic treatment most patients in moderate to advance stages of PD experience progressively increasing disabilities [4]. At this stage of the disease motor fluctuations are almost inevitable with levodopa treatment [5], and calls for the initiation of device-aided therapies once the criteria for these therapies are met [6]. Moreover, motor fluctuations are often accompanied by non-motor fluctuations, adding to a separate complexity and the decline in perceived quality of life [7]. When fluctuations occur, treatment aims should shift from oral medication to more continuous dopaminergic stimulation in the form of device-aided therapies [8], not in the least as these therapies also have a positive effect on many non-motor symptoms, and thus improve quality of life for PD patients $[9,10]$. Currently available device-aided therapies are deep brain stimulation (DBS), intrajejunal Levodopa-carbidopa infusion (IJLI) and continuous subcutaneous apomorphine infusion (CSAI).

DBS, of either the subthalamic nucleus (STN) or globus pallidus internus (GPI), was approved by the
US Food and Drug Administration in 2002 as a treatment option for PD, although the technique had been in use since the 1980s [11]. Randomized clinical trials have confirmed its effectiveness in improvement of motor and non-motor symptoms as well as quality of life in moderated and advanced stages of PD [9, $10,12,13]$. Also for CSAI and IJLI numerous studies have shown that these two treatments are clinically useful and efficacious in improving levodopa induced dyskinesias and other motor complications of PD [14]. In addition, all three device-aided treatments have a differential effect on non-motor symptoms of PD $[9,10]$. Despite the clear effectiveness of deviceaided therapies in the management of both motor and non-motor symptoms in advanced PD, concerns continue to exist regarding the high costs associated with these therapies. Here, economic evaluations are useful to assess their cost-effectiveness, aiding in decision-making of when to introduce these therapies in PD patients, in addition to the choice of deviceaided therapy type.

Therefore, we aimed to perform a systematic review of the available literature on economic analyses of device-aided therapies in patients with PD. Additionally, we looked at ongoing efforts to reduce the costs associated with these therapies.

\section{METHODS}

In this systematic review, we aimed to address the following clinical questions:

1. What is the cost-effectiveness of CSAI treatment in PD patients compared to best medical treatment using oral formulations?

2. What is the cost-effectiveness of IJLI in PD patients compared to best medical treatment using oral formulations?

3. What is the cost-effectiveness of DBS in PD patients compared to best medical treatment using oral formulations?

4. What strategies are currently being undertaken to reduce costs associated with device-aided therapies? 
Table 1

Search queries

\begin{tabular}{llc}
\hline Database & Query & Number of records \\
\hline PubMed & $\begin{array}{l}\text { parkinson's disease[MeSH Terms] AND } \\
\text { (levodopa infusion OR apomorphine[MeSH Terms] OR } \\
\text { deep brain stimulation[MeSH Terms]) AND cost }\end{array}$ & 248 \\
\end{tabular}

References used in the current review were identified by performing a systematic search in the PubMed and Web of Science databases in accordance with the Preferred Reporting Items for Systematic Reviews and Meta-Analyses (PRISMA) statement [15]. The search query was based on the PICO strategy and included 1) Population: advanced PD; 2) Intervention: CSAI, IJLI, or DBS; 3) Context/setting: all countries; and 4) Outcomes: cost-effectiveness of device-aided therapies. We determined time horizon of the intervention of at least one year. The time span of the search ranged from 1988 to April 2020. For PubMed, we used the Medical Subject Heading (MeSH) term "Parkinson's disease" combined with the terms "Apomorphine", "Levodopa Infusion" or "Deep Brain Stimulation", and "Cost" (Table 1). All MeSH terms were expanded to include all subhead- ings to identify all relevant articles. All potentially eligible manuscripts were considered regardless of publication type or language. The final search was performed in April 2020. In addition, reference lists of identified articles were screened for further potentially relevant papers. Articles were selected based on the following eligibility criteria: (1) original research, and (2) performed in PD patients. The search query is shown in Table 1 and the study selection process is shown in Fig. 1.

As universal guidelines on what is considered cost-effective are lacking, and marked differences in reimbursement policies exist between countries, we decided to use the gross domestic product per capita (GDP) as a threshold for cost-ineffectiveness [16]. The GDP of each country in the year in which a study was performed was used to determine whether
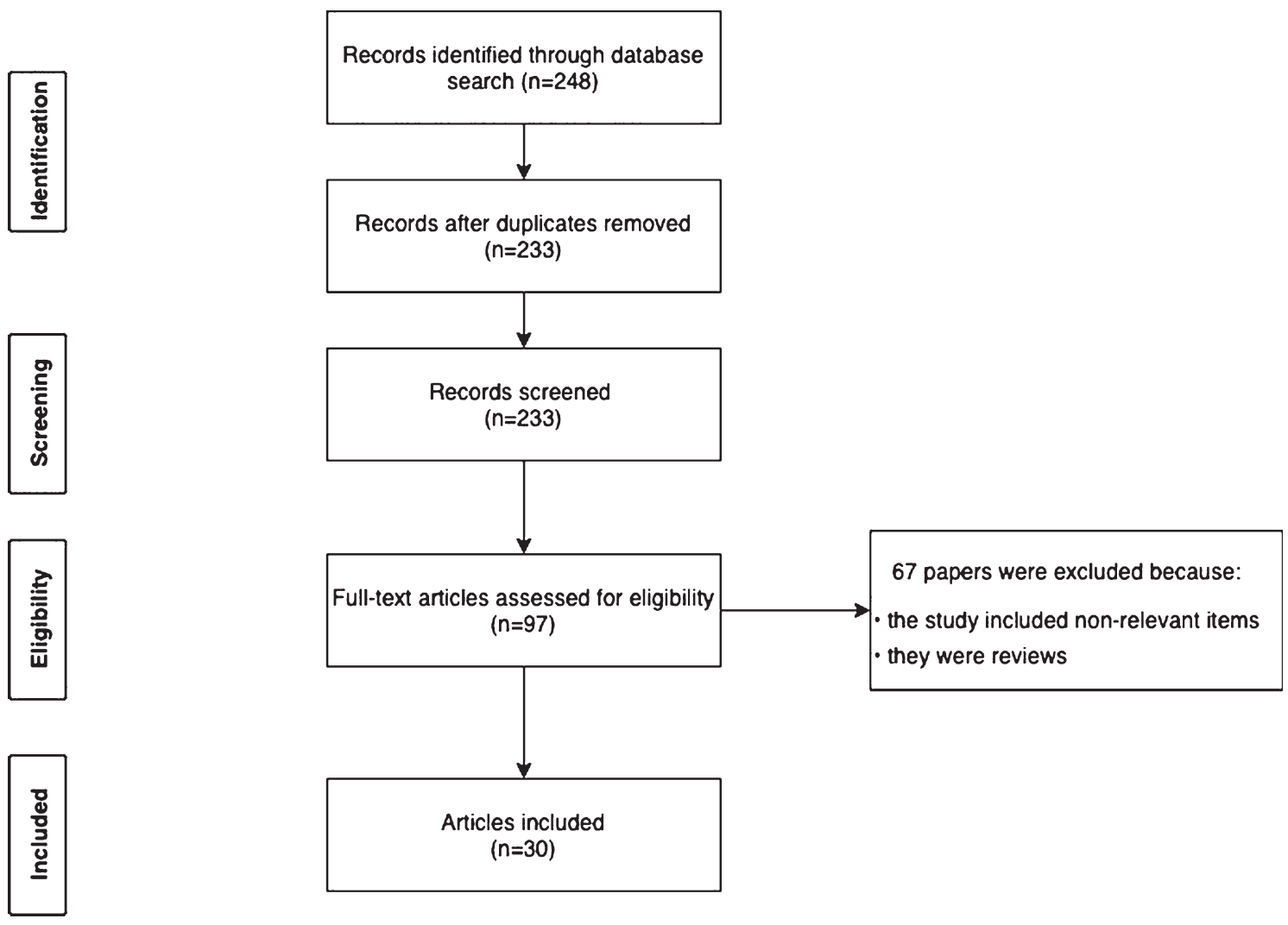

Fig. 1. Study selection process. 
the device-aided therapy studied was cost-effective (defined by a cost beneath the GDP of the respective country). Information on GDP was downloaded from the Organisation for Economic Co-operation and Development [17]. All costs not provided in euro were converted to euro based on the average exchange rate for the year (http://www.xe.com) in which the analysis for each included manuscript was conducted.

In addition to the aforementioned aims we have included manuscripts identifying implementation barriers of device-aided therapies in PD. For this, articles were selected based on their relevance and these were not included in the systematic search as this was not the primary aim of this review.

\section{RESULTS}

An overview of cost-effectiveness for the respective device-aided therapies is provided in Table 2. In total, 248 articles were retrieved from the database search by the query. Based on the selection process, 30 articles were included (Fig. 1); 30 on cost-effectiveness analyses for the device-aided therapies and a further three manuscripts on current efforts to reduce costs in these therapies.

\section{Cost-effectiveness}

\section{Intrajejunal levodopa infusion}

To date, 10 studies have looked into the cost-effectiveness for IJLI in PD patients with cohorts ranging from 10 to 354 patients [16, 18-26]. Eight studies have performed a cost-effectiveness analysis (CEA), of which one looked at costs per point UPDRS improvement, and two studies did not perform a CEA. A summary of the findings in the eight studies where a CEA on IJLI costs was performed, is provided in Table 2.

In general, in studies with the smallest sample size, there was a tendency for IJLI, although beneficial for quality of life and motor function, to be more expensive per Quality Adjusted Life Year (QALY) than standard treatment $[18,23]$ (Table 2). On the other hand, Kamusheva et al. [16] found that IJLI was costeffective for PD patients with prolonged akinesia. Here, it was observed that the additional annual cost was 1903.56 BGN ( $€ 971.01)$ for patients treated with IJLI, far below the recommended threshold of annual GDP per capita of Bulgaria (Table 2). In the UK, Lowin et al. showed that IJLI treatment was associated with an incremental cost per QALY of $£ 36,024$ $(€ 41,407)$ [22], slightly above the GDP threshold of the UK in 2011 when this study was published. The discrepancy between these results may be found in the difference in reporting the gain of IJLI. Whereas in the Bulgarian study the costs were expressed as those for one point improvement in UPDRS, in the Lowin et al. study a more conventional method of cost per QALY was adapted. Improvement in UPDRS scores does not necessarily imply an improvement in quality of life. Moreover, the latter study employed a Markov model instead of direct real-life data.

In the larger cohorts and in those with longer follow-up, among others in the United Kingdom, Germany and Ireland, the cost-effectiveness of IJLI was more favourable. Although Walter \& Odin demonstrated that the incremental costs for IJLI were considerable, with an incremental cost effectiveness ratio (ICER) of $£ 120,950(€ 165,685)$ in the UK and $€ 188,864$ in Germany [24], Lowin et al. showed much lower costs associated with IJLI treatment. The latter authors showed that the incremental costeffectiveness ratio for IJLI versus standard care was $€ 26,944$ per QALY (total costs and QALYs for IJLI and standard care, respectively, were $€ 537,687$ and $€ 514,037$ and 4.37 vs 3.49 ), resulting in a cost per QALY gained of $€ 26,944$ [21], well within the UK's GDP at that time (Table 2). The differences in ICER between the two studies may be explained by the differences in temporal horizon which was lifetime for Lowin et al., and three years for Walter \& Odin [22, 24]. It seems unlikely that these differences in costeffectiveness was caused by the fact whether a study was sponsored by a pharmaceutical industry or not. Both studies received sponsor funding, and also when extending this to the other included studies, no clear pattern could be observed between sponsor funded studies and studies which did not receive such funding (Table 2).

Kalabina et al. recently confirmed that in the United Kingdom a considerable incremental gain in QALYs can be achieved for patients treated with IJLI of 1.26 QALY with an ICER of $£ 52,110$ $(€ 59,215.91)$ with a temporal horizon of lifetime use [26]. Importantly, the authors also showed that, as advanced stage PD patients often require continuous care, the QALY gain allowed patients to remain independent for longer and, as such, reduce societal and informal care burden. When this caregiver disutility was included in the analysis the ICER associated with IJLI was reduced to $£ 47,266$ ( $€ 53,711.36$ ) [26]. In Sweden, Palhagen et al. looked at the costs associated with IJLI, although they did not perform a costeffectiveness analysis. Nevertheless, they showed 
Table 2

Cost-effectiveness of advanced therapies in Parkinson's disease

\begin{tabular}{|c|c|c|c|c|c|c|c|c|c|c|c|c|c|c|c|}
\hline \multicolumn{16}{|c|}{ Deep brain stimulation } \\
\hline Study & Country & $\begin{array}{c}\text { Type } \\
\text { of Study }\end{array}$ & $\begin{array}{c}\text { Cost of } \\
\text { Intervention }\end{array}$ & $\begin{array}{c}\text { QALYs } \\
\text { intervention }\end{array}$ & Comparator & $\begin{array}{c}\text { Cost of } \\
\text { Comparator }\end{array}$ & $\begin{array}{c}\text { QALYs } \\
\text { Comparator }\end{array}$ & $\begin{array}{l}\text { Temporal } \\
\text { Horizon }\end{array}$ & $\begin{array}{c}\text { Discount } \\
\text { Rate } \\
\end{array}$ & ICER & $\begin{array}{c}\text { Difference } \\
\text { in QALY }\end{array}$ & $\begin{array}{c}\text { Incremental } \\
\text { Cost }\end{array}$ & $\begin{array}{c}\text { GDP/capita } \\
\text { threshold }\end{array}$ & $\begin{array}{c}\text { Cost- } \\
\text { effectve?* }\end{array}$ & $\begin{array}{c}\text { Sponsor } \\
\text { bias? }\end{array}$ \\
\hline $\begin{array}{l}\text { Tomaszewski } \\
\text { and Holloway, } \\
2001 \text { [35] }\end{array}$ & $\begin{array}{l}\text { United } \\
\text { States }\end{array}$ & CUA & $\begin{array}{c}\$ 452,000 \\
(€ 502,222)\end{array}$ & 7.8 & BMT & $\begin{array}{c}\$ 417,000 \\
(€ 463,333)\end{array}$ & 7.08 & Lifetime & $3 \%$ & $\begin{array}{c}\$ 49,194 \\
(€ 54,660)\end{array}$ & 0.72 & $\begin{array}{c}\$ 35,000 \\
(€ 38,889)\end{array}$ & $\$ 37,100$ & Yes & $\begin{array}{l}\text { Not } \\
\text { sponsor } \\
\text { funded }\end{array}$ \\
\hline $\begin{array}{l}\text { Gerzeli } \\
\text { et al., } \\
2002 \text { [69] }\end{array}$ & Italy & Costs & $€ 20,033$ & NA & BMT & $€ 8,976$ & NA & $1 y$ & NA & NS & NA & $€ 11,057$ & $\$ 28.716$ & Yes & $\begin{array}{l}\text { Sponsor } \\
\text { funded }\end{array}$ \\
\hline $\begin{array}{l}\text { Meissner } \\
\text { et al., } \\
2005 \text { [70] }\end{array}$ & Germany & CEA & $€ 28,305$ & NA & BMT & $€ 15,991$ & NA & $2 y$ & $5 \%$ & NS & NA & $€ 12,314$ & $\$ 32,237$ & Yes & $\begin{array}{l}\text { Not } \\
\text { sponsor } \\
\text { funded }\end{array}$ \\
\hline $\begin{array}{l}\text { Valldeoriola } \\
\text { et al., } \\
2007 \text { [27] }\end{array}$ & Spain & CUA & $€ 27,614$ & 0.7611 & BMT & $€ 20,013$ & 0.5401 & $1 \mathrm{y}$ & NA & $€ 34,389$ & 0.221 & $€ 7,601$ & $\$ 32,429$ & Yes & $\begin{array}{c}\text { Not } \\
\text { sponsor } \\
\text { funded }\end{array}$ \\
\hline $\begin{array}{l}\text { Dams } \\
\text { et al., } \\
2013 \text { [34] }\end{array}$ & Germany & CUA & $€ 133,174$ & 11.62 & BMT & $€ 126,180$ & 10.58 & Lifetime & $3 \%$ & $€ 6,677$ & 1.05 & $€ 6,994$ & $\$ 44,994$ & Yes & $\begin{array}{c}\text { Not } \\
\text { sponsor } \\
\text { funded }\end{array}$ \\
\hline $\begin{array}{l}\text { Valldeoriola } \\
\text { et al., } \\
2013 \text { [32] }\end{array}$ & Spain & CEA & $€ 103,730$ & NA & $\begin{array}{c}\text { IJLI } \\
\text { CSAI }\end{array}$ & $\begin{array}{l}€ 247,918 \\
€ 160,150\end{array}$ & $\begin{array}{l}\text { NA } \\
\text { NA }\end{array}$ & $5 y$ & NS & NS & $\begin{array}{l}\text { NA } \\
\text { NA }\end{array}$ & $\begin{array}{c}€-144,188 \\
€-56,420\end{array}$ & $\begin{array}{l}\text { N/A } \\
\text { N/A }\end{array}$ & $\begin{array}{l}\text { N/A } \\
\text { N/A }\end{array}$ & $\begin{array}{c}\text { Sponsor } \\
\text { funded }\end{array}$ \\
\hline $\begin{array}{l}\text { Eggington } \\
\text { et al., } \\
2014 \text { [31] }\end{array}$ & $\begin{array}{c}\text { United } \\
\text { Kingdom }\end{array}$ & CUA & $\begin{array}{c}£ 68,970 \\
(€ 101,426)\end{array}$ & 2.21 & BMT & $\begin{array}{c}£ 48,243 \\
(€ 70,946)\end{array}$ & 1.21 & $5 y$ & $3.5 \%$ & $\begin{array}{c}£ 20,678 \\
(€ 30,409)\end{array}$ & 1,002 & $\begin{array}{c}£ 20,727 \\
(€ 30,481)\end{array}$ & $\$ 41,269$ & Yes & $\begin{array}{r}\text { Sponsor } \\
\text { funded }\end{array}$ \\
\hline $\begin{array}{l}\text { Zhu } \\
\text { et al., } \\
2014 \text { [29] }\end{array}$ & China & CUA & $\begin{array}{c}\$ 398,110 \\
(€ 299,331)\end{array}$ & 0.855 & BMT & $\begin{array}{l}\$ 107,258 \\
(€ 80,645)\end{array}$ & 0.5 & $2 \mathrm{y}$ & $3 \%$ & $\begin{array}{c}\$ 24,868 \\
(€ 18,698)\end{array}$ & 0.355 & $\begin{array}{c}\$ 1,347 \\
(€ 1,013)\end{array}$ & $\$ 13,459$ & Yes & $\begin{array}{l}\text { Not } \\
\text { sponsor } \\
\text { funded }\end{array}$ \\
\hline \multirow[t]{2}{*}{$\begin{array}{l}\text { Walter \& } \\
\text { Odin, } \\
2015 \text { [24] }\end{array}$} & UK & CEA & $\begin{array}{c}£ 87,730 \\
(€ 120,178)\end{array}$ & 2.75 & BMT & $\begin{array}{c}£ 76,793 \\
(€ 105,196)\end{array}$ & 2.62 & 3 years & $3.5 \%$ & NS & 0.13 & $\begin{array}{c}£ 10,937 \\
(€ 14,982)\end{array}$ & $\$ 42,522$ & Yes & $\begin{array}{r}\text { Sponsor } \\
\text { funded }\end{array}$ \\
\hline & Germany & CEA & $€ 105,737$ & 2.85 & BMT & $€ 90,012$ & 2.73 & 3 years & $3 \%$ & NS & 0.12 & $€ 15,725$ & $\$ 47,684$ & Yes & \\
\hline $\begin{array}{l}\text { Pietzsch } \\
\text { et al., } \\
2016 \text { [37] }\end{array}$ & USA & CEA & $\begin{array}{c}\$ 130,510 \\
(€ 117,577)\end{array}$ & 3.19 & BMT & $\begin{array}{c}\$ 91,026 \\
(€ 82,005)\end{array}$ & 1.50 & $10 \mathrm{y}$ & $3 \%$ & $\begin{array}{c}\$ 23,404 \\
(€ 21,085)\end{array}$ & 1.69 & $\begin{array}{c}\$ 19,571 \\
(€ 17,632)\end{array}$ & $\$ 57,884$ & Yes & $\begin{array}{c}\text { Sponsor } \\
\text { funded }\end{array}$ \\
\hline $\begin{array}{l}\text { Fundament } \\
\text { et al., } \\
2016[28]\end{array}$ & UK & CEA & $\begin{array}{c}£ 73,077 \\
(€ 89,118)\end{array}$ & 6.69 & BMT & $\begin{array}{c}£ 46,278 \\
(€ 56,437)\end{array}$ & 5.35 & $15 y$ & $3,5 \%$ & $\begin{array}{c}£ 19,887 \\
(€ 24,252)\end{array}$ & 1.34 & $\begin{array}{c}£ 26,799 \\
(€ 32,682)\end{array}$ & $\$ 44,138$ & Yes & $\begin{array}{r}\text { Sponsor } \\
\text { funded }\end{array}$ \\
\hline $\begin{array}{l}\text { Kawamoto } \\
\text { et al., } \\
2016 \text { [71] }\end{array}$ & Japan & CEA & $\begin{array}{c}\$ 144,600 \\
(€ 130,270)\end{array}$ & NS & BMT & NS & NS & NS & NS & NS & 6.7 & $\begin{array}{c}\$ 25,600 \\
(€ 23,063)\end{array}$ & $\$ 39,990$ & Yes & $\begin{array}{c}\text { Not } \\
\text { sponsor } \\
\text { funded }\end{array}$ \\
\hline
\end{tabular}


Table 2

(Continued)

\begin{tabular}{|c|c|c|c|c|c|c|c|c|c|c|c|c|c|c|c|}
\hline \multicolumn{16}{|c|}{ Deep brain stimulation } \\
\hline Study & Country & $\begin{array}{c}\text { Type } \\
\text { of Study }\end{array}$ & $\begin{array}{c}\text { Cost of } \\
\text { Intervention }\end{array}$ & $\begin{array}{c}\text { QALYs } \\
\text { intervention } \\
\end{array}$ & Comparator & $\begin{array}{c}\text { Cost of } \\
\text { Comparator }\end{array}$ & $\begin{array}{c}\text { QALYs } \\
\text { Comparator } \\
\end{array}$ & $\begin{array}{l}\text { Temporal } \\
\text { Horizon }\end{array}$ & $\begin{array}{c}\text { Discount } \\
\text { Rate } \\
\end{array}$ & ICER & $\begin{array}{l}\text { Difference } \\
\text { in QALY }\end{array}$ & $\begin{array}{c}\text { Incremental } \\
\text { Cost }\end{array}$ & $\begin{array}{c}\text { GDP/capita } \\
\text { threshold }\end{array}$ & $\begin{array}{c}\text { Cost- } \\
\text { effectve?* }\end{array}$ & $\begin{array}{c}\text { Sponsor } \\
\text { bias? }\end{array}$ \\
\hline $\begin{array}{l}\text { Dams } \\
\text { et al., } \\
2016 \text { [36] }\end{array}$ & Germany & CEA & $€ 151,800$ & 13.84 & BMT & $€ 115,400$ & 12.25 & Lifetime & $3 \%$ & $€ 22,710$ & 1.59 & $€ 36,400$ & $\$ 50,564$ & Yes & $\begin{array}{r}\text { Sponsor } \\
\text { funded }\end{array}$ \\
\hline $\begin{array}{l}\text { Vivancos- } \\
\text { Matellano } \\
\text { et al., } \\
2016[25]^{*} \\
\text { review }\end{array}$ & Spain & CEA & $€ 89,477$ & 2.80 & $\begin{array}{c}\text { IJLI } \\
\text { CSAI }\end{array}$ & $\begin{array}{l}€ 234,643 \\
€ 110,348\end{array}$ & $\begin{array}{l}3.12 \\
2.89\end{array}$ & 5 years & $3.5 \%$ & $\begin{array}{c}\text { NS } \\
€ 245,541\end{array}$ & $\begin{array}{l}-0.32 \\
-0.09\end{array}$ & $\begin{array}{l}-€ 145,166 \\
-€ 20,817\end{array}$ & $\begin{array}{l}\text { N/A } \\
\text { N/A }\end{array}$ & $\begin{array}{l}\text { N/A } \\
\text { N/A }\end{array}$ & $\begin{array}{c}\text { Not } \\
\text { sponsor } \\
\text { funded }\end{array}$ \\
\hline $\begin{array}{l}\text { McIntosh } \\
\text { et al., }\end{array}$ & UK & CEA & $\begin{array}{c}£ 19,069 \\
(€ 23,255)\end{array}$ & 0.0286 & BMT & $\begin{array}{c}£ 9,813 \\
(€ 11,967)\end{array}$ & 0.0088 & 1 year & $3.5 \%$ & $\begin{array}{c}£ 468,528 \\
(€ 571,376)\end{array}$ & 0.02 & $\begin{array}{c}£ 9,256 \\
(€ 11,288)\end{array}$ & $\$ 44,138$ & Yes & $\begin{array}{r}\text { Sponsor } \\
\text { funded }\end{array}$ \\
\hline & & & $\begin{array}{c}£ 113,075 \\
(€ 137,896) \\
\end{array}$ & 4.66 & BMT & $\begin{array}{r}£ 71,146 \\
(€ 86,763) \\
\end{array}$ & 4,06 & 10 years & $3.5 \%$ & $\begin{array}{c}£ 70,537 \\
(€ 86,021) \\
\end{array}$ & 0.60 & $\begin{array}{c}£ 41,929 \\
(€ 51,133) \\
\end{array}$ & $\$ 44,138$ & No & \\
\hline \multicolumn{16}{|c|}{ Intrajejunal Levodopa Infusion } \\
\hline $\begin{array}{l}\text { Kristiansen } \\
\text { et al., } \\
2009 \text { [18] }\end{array}$ & Sweden & CEA & $\begin{array}{c}\text { SEK } \\
562,000\end{array}$ & 1.48 & BMT & $\begin{array}{c}\text { SEK } \\
172,000\end{array}$ & 1.42 & 2 years & $3 \%$ & 0.06 & $\begin{array}{c}\text { SEK } \\
390,000\end{array}$ & $\begin{array}{c}\text { SEK } \\
6,100,000 \\
(€ 665,213)\end{array}$ & $\$ 40,187$ & No & $\begin{array}{r}\text { Sponsor } \\
\text { funded }\end{array}$ \\
\hline $\begin{array}{l}\text { Lowin } \\
\text { et al., } \\
2011 \text { [22] }\end{array}$ & UK & CEA & $£ 201,192$ & 1.88 & BMT & $£ 161,548$ & 0.78 & Lifetime & NS & 1.10 & $£ 39,644$ & $\begin{array}{c}£ 36,024 \\
(€ 41,407)\end{array}$ & $\$ 37,146$ & No & $\begin{array}{r}\text { Sponsor } \\
\text { funded }\end{array}$ \\
\hline $\begin{array}{l}\text { Kamusheva } \\
\text { et al., } \\
2013 \text { [16] }\end{array}$ & Bulgaria & CEA & $\begin{array}{c}\text { BGN } \\
5,655.91\end{array}$ & $\begin{array}{c}57.42 \\
\text { (UPDRS) }\end{array}$ & BMT & $\begin{array}{c}\text { BGN } \\
143.49\end{array}$ & $\begin{array}{c}22.67 \\
\text { (UPDRS) }\end{array}$ & NS & NS & $\begin{array}{c}34.75 \\
\text { (UPDRS) }\end{array}$ & $\begin{array}{c}\text { BGN } \\
1903.56\end{array}$ & $\begin{array}{c}\text { BGN } \\
158.63(€ 81.45) \\
\text { per point } \\
\text { UPDRS }\end{array}$ & $\$ 16,582$ & Yes & $\begin{array}{r}\text { Sponsor } \\
\text { funded }\end{array}$ \\
\hline $\begin{array}{l}\text { Lundqvist } \\
\text { et al., } \\
2014 \text { [23] }\end{array}$ & Norway & CEA & $\begin{array}{c}\text { NOK } \\
890,920\end{array}$ & 0.68 & BMT & $\begin{array}{c}\text { NOK } \\
419,160\end{array}$ & 0.63 & 1 year & NS & 0.05 & $\begin{array}{c}\text { NOK } \\
471,760\end{array}$ & $\begin{array}{c}\text { NOK } \\
9,200,000 \\
(€ 1,180,000)\end{array}$ & $\$ 65,986$ & No & $\begin{array}{l}\text { Not } \\
\text { sponsor } \\
\text { funded }\end{array}$ \\
\hline $\begin{array}{l}\text { Walter \& } \\
\text { Odin, }\end{array}$ & UK & CEA & $£ 130,011$ & 3.06 & BMT & $£ 76,793$ & 2.62 & 3 years & $3.5 \%$ & 0.44 & $£ 53,218$ & $\begin{array}{l}£ 120,950 \\
(€ 165,685)\end{array}$ & $\$ 42,522$ & No & $\begin{array}{c}\text { Sponsor } \\
\text { funded }\end{array}$ \\
\hline 2015 [24] & Germany & CEA & $€ 175,004$ & 3.18 & BMT & $€ 90,012$ & 2.73 & 3 years & $3 \%$ & 0.45 & $€ 84,989$ & $€ 188,864$ & $\$ 47,684$ & No & \\
\hline $\begin{array}{l}\text { Vivancos- } \\
\text { Matellano } \\
\text { et al., } \\
2016 \text { [25] }\end{array}$ & Spain & CEA & $€ 234.643$ & 3.12 & CSAI & $€ 110,348$ & 2.89 & 5 years & $3.5 \%$ & 0.23 & $€ 124,295$ & $€ 75,206$ & $\$ 37,310$ & No & $\begin{array}{l}\text { Not } \\
\text { sponsor } \\
\text { funded }\end{array}$ \\
\hline *review & & & & & DBS & $€ 89,477$ & 2.80 & & & 0.32 & $€ 146,166$ & & $\$ 37,310$ & No & \\
\hline $\begin{array}{l}\text { Lowin } \\
\text { et al., } \\
2017 \text { [21] }\end{array}$ & UK & CEA & $€ 537,687$ & 4.37 & BMT & $€ 514,037$ & 3.49 & Lifetime & NS & 0.88 & $€ 23,650$ & $€ 26,944$ & $\$ 45,998$ & Yes & $\begin{array}{r}\text { Sponsor } \\
\text { funded }\end{array}$ \\
\hline
\end{tabular}


that monthly costs for PD patients on standard therapies compared to those on IJLI was similar $(€ 8,226)$, supporting the feasibility of IJLI [20].

\section{Apomorphine}

Unlike IJLI, only three studies have looked at the cost-effectiveness of continuous subcutaneous Apomorphine infusion (CSAI) and intermittent Apomorphine injections. Although not a classical cost-effectiveness analysis, Heald and colleagues described the reduction in costs associated with switching PD patients from oral treatments to non-oral treatments. They analysed data over a threeyear period in general practitioner practices in the United Kingdom and found that practices using oral therapies in PD patients incurred $£ 4,851(€ 6,613)$ of secondary care costs in addition to $£ 890(€ 1,213)$ primary prescribing costs per weighted patient per year. In contrast, practices prescribing Apomorphine incurred $£ 3,954$ (€5,390) per weighted patient, resulting in a saving of $£ 897(€ 1,223)$ per year with an additional cost of $£ 475$ ( $€ 648$ ) per patient per year for prescribing apomorphine [2]. In this study, it was noted that the costs savings for practices prescribing intermittent injections was greater than for those prescribing continuous infusion $(£ 423$ vs. $£ 41$ per patient per year), and interestingly the authors showed that prescribing non-oral medication (apomorphine and rotigotine in this analysis) could result in a reduction in the annual admission rate for PD patients of up to $28 \%$ [2].

The only true cost-effectiveness studies regarding CSAI were performed in 2015 in the United Kingdom and Germany, and in 2016 in Spain. Here, Walter and Odin described that the direct lifetime costs of continuous apomorphine infusion was estimated at $£ 78,251.49$ (€57,123.59) and generated 2.85 QALYs in the United Kingdom, and $€ 104,500.08$ and 2.92 QALYs in Germany (Table 2), showing this therapy was cost-effective in the UK, but not in Germany [24]. Also Vivancos-Matellano et al. showed that after five years CSAI was associated with a cost reduction of $€ 124,295$ compared to IJLI, and a cost increment of $€ 20,871$ compared to DBS, with an ICER of $€ 38,249$ per QALY [25], above the GDP of Spain (Table 2).

\section{Deep brain stimulation}

Seventeen articles investigated the cost-effectiveness of DBS in PD; nearly all studies compared DBS to BMT, but two studies compared DBS to the other device-aided therapies. The sample size 
varied from 29 [27] to 297 [28] patients per study. A detailed summary of the findings of studies is included in Table 2.

In the studies with one or two year temporal horizons the incremental costs ranged between $€ 1,013$ in a Chinese study [29] to $€ 11,288$ in a study performed in the UK [30], although not all studies performed a CEA. In the studies that did provide an ICER the costs per QALY ranged between $€ 18,698$ and $€ 571,376[27,29,30]$. The wide range between these studies is not only explained by difference in prices for DBS between countries, but mainly by the small gain in QALY between DBS and BMT in the short term, with difference in QALY being as low as 0.02 [30] (Table 2).

In studies with a three or five year horizons the ICER for DBS decreases and the differences between studies becomes less pronounced. Here, it was observed that the ICER can be as low as $€ 21,085$ in the UK [24], with the upper limit being at $€ 30,409$ [31] (Table 2). In comparison to the other deviceaided therapies DBS had the most favourable costeffectiveness profile $[25,32]$. This reduction in costs after the first few years of DBS implantation was also noted by others, where it was observed that the costs of DBS were highest during the first year and included mainly the costs of the device, surgery and hospitalisation, after which they decreased until battery replacement [33, 34].

In the studies with a temporal horizon of 10 years or more (up to life-time), the tendency for decreasing costs associated with DBS becomes clearer. Here, for example, Tomaszewski et al. showed that total lifetime costs were $\$ 452,000$ for STN DBS and $\$ 417,000$ for BMT. QALYs gained were 7.80 and 7.08, respectively, resulting in an ICER of $\$ 49,194(€ 54,660)$ [35]. Compared to the results of Dams et al. both costs and utilities were high, as in the latter study the ICER was only $€ 6,677$ [34]. Incremental costs, however, were similar and it should be noted the studies were performed 12 years apart [36].

A similar low ICER was noted in the studies by Pietzsch et al. and Fundament and colleagues [28, 37], yet could not be confirmed in a UK based study were the ICER was $€ 86,021$ due to the only modest QALY gain of 0.60 of DBS compared to BMT [30] (Table 2). Interestingly, even in PD patients with early stage disease the ICER of STN DBS can be relatively low at $€ 22,710$ [36].

The discrepancy between the included DBS studies can result from differences in the context-specific costs and utility calculations, however all included studies showed that DBS is cost-effective. Additionally, differences between studies in terms of participants' severity of PD and the duration of motor fluctuations may have had an impact on direct costs $[38,39]$. This was also demonstrated by Espey et al. who compared early vs late DBS and reported 2.5 additional QALYs for early initiation of DBS. Assuming a lifelong time horizon for cost-effectiveness calculations this may have resulted in a benefit compared to studies that employed a relatively later initiation of DBS [40].

\section{Comparison of the three advanced therapies}

Three studies have compared the advanced therapies for PD in terms of cost-effectiveness. Valldeoriola et al. have compared all three therapies and found that the mean cumulative five-year cost per patient was lowest in patients treated with DBS $(€ 88,014)$, and highest in those on IJLI $(€ 233,986)$ (costs associated with apomorphine infusion were $€ 141,393)$. Despite initial high costs associated with DBS $(32.3 \%$ of the total five-year costs for this therapy), yearly average started decreasing in the second year post-intervention with costs of $€ 17,603$, compared to $€ 46,797$ for IJLI and $€ 28,279$ for apomorphine infusion [32].

In the PND27 Study, performed in the United Kingdom, it was estimated that the discounted costs over five years were $£ 69,566$ and $£ 80,843$ for DBS and apomorphine infusion, respectively, resulting in a cost savings of $£ 11,277$ for DBS. In this study cost savings for DBS started from the third year postintervention, with the initial costs of implantation of the DBS device offset by the ongoing need for apomorphine drug provision [41]. Finally, as mentioned before, Vivancos-Matellano and colleagues showed that CSAI was associated with a 5-year cost reduction of $€ 124,295$ compared to IJLI, and a cost increment of $€ 20,871$ compared to DBS [25] (Table 2).

\section{Device-aided therapy cost reduction efforts}

As evidenced in Table 2 most studies with a temporal horizon of five years or over show that the ICER for the three device-aided was less than or only slightly above the GDP for the countries where the respective studies were conducted. As such, it may be concluded that most device-aided therapies are or have the potential to be, in the long-term, costeffective, although this is more clear for DBS than for the infusion therapies. In order to further reduce the 
costs associated with device aided therapies, specifically the infusion therapies, several efforts have been undertaken.

For DBS, rechargeable implantable pulse generators (IPGs) are currently the most promising effort to reduce costs and can also influence higher patient satisfaction associated with reduction of the burden of frequent recharging. Cost analyses revealed that the estimated reduction of costs are approximately $€ 1,000-2,000$ per patient per year over the lifespan of the rechargeable IPG (estimated at 9 years for the Activa RC) $[42,43]$.

One of the most promising strategies to reduce costs associated with LCIG is the introduction of catechol-O-methyltransferase (COMT) inhibition either added to the LCIG infusion suspension, or as an add-on therapy. By adding Entacapone to the LCIG suspension (LECIG), Senek et al. were able to show that the Levodopa dose for some patients could be decreased by more than $20 \%$, e.g., by decreasing maintenance dose flowrate while treatment response scores did not change [44]. This LECIG combination is now being marketed in some northern European countries with a price identical to LCIG (around $€ 155)$ [45]. Similarly, by adding oral Opicapone, a new third-generation COMT inhibitor, in patients on LCIG a reduction of $24.8 \%$ in LCIG daily dose could be achieved, without changes in motor performance, including stable dyskinesia levels. Moreover, a theoretical net average cost savings of $£ 21,497.88$ $(€ 24,518.33)$ per patient per year could be achieved [46]. Even though these strategies need to be explored further, they offer hope that the high costs of LCIG and the associated costs per QALY currently over the GDP threshold could be reduced. To our knowledge, there are no strategies underway to reduce CSAI costs.

Other factors that should be taken into account when discussing the potential of cost reduction, are caregiver burden and other medical costs, as improvements in these factors are likely to further reduce the costs associated with device-aided therapies. As shown in studies for LCIG, taking into account caregiver disutility the costs per QALY could be reduced by almost $10 \%$ [26]. In addition, general practitioner practices in the UK prescribing device-aided therapies (apomorphine) are capable of monthly savings on other healthcare costs and up to a $28 \%$ reduction in the annual admission rate for PD patients [2].

Other factors to take into account, are indirect costs which include lost productivity (e.g., the costs due to premature retirement, reduction of working hours, and sick and disability leave) and formal and informal care (e.g., unpaid help from others for everyday activities) [47]. The latter has been demonstrated to be the greatest component of societal and family burden associated with $5 \%$ of total costs of which $80 \%$ are the costs related to informal care [48]. Other cost-driving factors that have been reported across several countries include premature retirement [39]. Indirect costs associated with premature retirement in PD ranged from $€ 860$ (95\% CI: $€ 630-€ 1090)$ in Russia to $€ 3,910$ (95\% CI: $€ 2,510-€ 6,140)$ in Austria and accounted for 30-68\% of all PD costs. However, such indirect costs are rarely and incompletely reported in cost analysis studies [39, 47]. If device-aided therapies are able to improve these factors, and thereby reduce indirect costs, this will make them more cost-effective in the long term.

\section{DISCUSSION}

Based on the available evidence all three deviceaided therapies in PD, DBS, CSAI and IJLI, are able to improve quality of life compared to best medical treatment with oral therapies, with improvements between 0.88 and 1.26 QALY in the studies with long temporal horizons. This improvement appears to be more pronounced for IJLI than CSAI and DBS, although studies directly comparing these three device-aided therapies are few. Nonetheless, these improvements in quality of life are substantial and certainly merit serious consideration in view of the prevailing cost-effectiveness criteria. Based on the criteria used in the current review we have shown that DBS is a cost-effective device-aided treatment for $\mathrm{PD}$, but this picture is less uniform for the infusion therapies.

Whether or not therapies are deemed cost-effective often depends on health authority regulations in individual countries. In the UK, where many of the included studies in this review were performed, the National institute for Health and Care excellence (NICE) will often only appraise a technology or new medication if the ICER is less than $£ 20,000$ per QALY gained, and it is unlikely to approve interventions with an ICER of $£ 30,000$ or over per QALY gained. Exceptions are made if a therapy has a very clear treatment effect and offers additional effects beyond standard therapy [49]. However, this situation is not uniform and the 'willingness to pay' per QALY differs vastly across countries [50]. In 2018, the range of costs per QALY for diseases 
in general that different European countries were willing to pay ranged from $\$ 19,006(€ 16,107)$ in Poland to $\$ 180,653(€ 153,096)$ in Belgium [50], although these numbers do not need necessarily apply to PD. As such, it is unlikely that all deviceaided therapies will be approved in every country in Europe, mainly IJLI which is the most expensive device-aided therapy. Although fixed criteria to assess whether an intervention is cost-effective are lacking and differ from country to country, some studies have proposed, e.g., the one by Laupacis et al., that treatment was considered cost-effective if the costs were below $€ 50,000 / \mathrm{QALY}$ [51]. Other approaches, including the one we deployed in the current review, suggest that the ICER should be below the gross domestic product (GDP) of a country per capita [16]. GDP as a benchmark to evaluate cost-effectiveness of a therapy has been promoted by the World Health Organization's Choosing Interventions that are Cost-Effective (WHO-CHOICE) project [52]. However, it has been also argued that the thresholds based on per capita GDP had major shortcomings and should be abandoned as guides for policy-makers [53]. Thus, the appropriate measure and threshold of cost-effectiveness remains controversial and there are still no established and commonly accepted criteria. Furthermore, it is a commonplace that therapies that are considered sufficiently promising and therefore get funded often develop (due to scientific and technological progress) and become more cost effective over time [54]. That is why it may be reasonable to fund some particularly beneficial therapies even despite their relative low cost-effectiveness rate. Practical applicability of a therapy may create an incentive to develop it further to become more cost-effective, while its rejection due to insufficient cost-effectiveness (irrespective of its medical effects) usually impairs its potential for improvement, including cost-benefit ratios. It entails that even a relatively low cost-effectiveness of a therapy may, at least in some cases, be compensated by strictly medical effectiveness accompanied by a potential for further technological development reducing its costs.

In addition to the ICER for the three device-aided therapies being within the 'willingness-to-pay' limits per QALY for most countries for which such data is available, the introduction of these therapies in the complicated stages of PD may have further benefits. Although not usually included in the costeffectiveness analyses as an outcome, some authors have suggested that cost savings might be achieved by a reduction in care giver burden and indirect costs associated with care. For example, Heald and colleagues demonstrated that in the UK the prescription of non-oral medication (apomorphine and rotigotine in this study) resulted in a reduced annual admission rate of up to $28 \%$ [2]. In this respect, it is interesting to note that Findley et al. found that cost of care for patients with advanced PD, calculated as direct non-medical and indirect costs, accounted for over $85 \%$ of total costs [55]. More specifically, the authors observed that direct non-medical costs of professional care in the UK accounted for $50 \%$ of costs, indirect informal care $43 \%$, whereas only $7 \%$ of total costs could be attributed to directly incurring medical costs. The latter was determined mostly by hospitalisation, followed by health professional visits and testing. In addition, when a caregiver is considered in cost-effectiveness analyses, one study looking at IJLI has shown that the gain in QALYs allows patients to remain independent for longer and, thereby, reduce societal and informal care burden. In terms of costs, this resulted in an additional $€ 5,500$ reduction in ICER [26].

Interestingly, most cost-effectiveness analyses in device-aided therapies have focused on the improvement of motor function as a driver for the improvement in quality of life and QALYs. Non-motor symptoms, however, have an at least equal, if not more important contribution to quality of life in PD [56]. Future analyses should include improvements of non-motor symptoms in their analyses as it is known that all device-aided therapies improve non-motor burden and have a differential effect on the spectrum of non-motor symptoms that improve, along with an associated improvement in quality of life $[9,10$, $12,57]$. In addition, indirect costs, such as a reduction in caregiver burden and reduced medical care costs, among others related to a reduction in hospital admissions, should be taken into account in future studies.

At first glance, when comparing the three deviceaided therapies, DBS appears to be the most costeffective therapies. However, certain limitations to this conclusion should be acknowledged. First and foremost, it should be realised that the patients that receive DBS, compared to those selected for infusion therapies, show certain differences in demographic characteristics. Patients selected for DBS are often younger and with a shorter disease duration than those selected for CSAI, and especially IJLI $[9,10]$, and per DBS protocols patients with cognitive decline or depression are not selected for DBS [58]. These 
latter restrictions are less stringent for the infusion therapies. As all these factors contribute to quality of life, both through increasing motor and non-motor burden with increasing age and disease duration, the improvements observed on quality of life after introduction of these therapies is unlikely to be comparable across groups. Additionally, and unlike the case for IJLI and CSAI, Dams et al. reported that DBS can be efficiently applied at an earlier stage of disease [36], as also recommended in guidelines. Despite the consistent observations that DBS is more costly then oral treatment, expenses can be justified by the gain in health advantages. The authors demonstrated that DBS can be applied in early stages of PD for a generally acceptable price of $€ 22,700 / \mathrm{Q} A L Y$ gained [36].

Choosing which device-aided treatment option is most suitable is not just a question of health economics, but requires a careful process, in which the patient's and carers' preferences and the clinician's expertise contribute equally to the decision. Nonetheless, the implementation of device-aided therapies in PD appears to be challenging and during this process one is regularly confronted with implementation barriers occurring in clinical practice [59]. First of all, even though PD patients need to be involved in a shared-decision making process, they often feel ill-equipped and unsupported by medical specialists, although this is country and healthcare system specific and need not apply to all situations [60]. Furthermore, selecting eligible patients for advanced therapies often appears to be a challenging task in clinical practice. The selection for all device-aided therapies in PD should carefully assess the following factors: disease duration, age, levodopa responsiveness, type and severity of levodopa-unresponsive symptoms, cognitive and psychiatric issues, comorbid disorders, and for DBS also brain magnetic resonance imaging (MRI) findings [61]. Moreover, neurologists regularly mention limited decision-making capabilities in PD patients as an additional barrier in patients with advanced PD, where increasing disease severity and associated cognitive deficits further complicate these capabilities [62]. Other factors of influence include the patient's place of residence, where, for example, patients in rural areas often have limited access to specialised centres providing device-aided therapies for PD [63]. This may lead to delayed referral and delayed consideration for non-oral treatments, causing a general under-treatment of advanced PD [60]. Related to this, patients are often first seen by a general neurologist, who may not have specialised knowledge regarding advanced treatments in PD, further influenced by the lack of access to multidisciplinary team care and lack

Table 3

Barriers for the implementation of advanced therapies in Parkinson's disease

\begin{tabular}{lc}
\hline Barrier & Reference \\
\hline Direct barriers & \\
Limited number of randomised trials directly comparing advanced & \\
treatments to guide treatment decision & {$[64]$} \\
Various patients are considered too late for advanced therapies, & \\
leading to general under-treatment of advanced PD & {$[72]$} \\
Limited expertise among clinicians due to a lack of treatment & {$[59,60]$} \\
experience or availability of advanced treatments & \\
PD patients are involved in the decision-making processes; & \\
however, they often feel ill-equipped and unsupported & \\
by the medical specialists. Neurologists mention limited \\
decision-making capacity in PD patients as an additional \\
barrier to SDM in advanced PD, related to disease severity, \\
and associated cognitive deficits \\
Treatment complications of advanced therapies, including \\
increased risk of falling or development of hallucinations \\
Other potential barriers \\
Pre-intervention: \\
- Appropriate patient selection \\
- Management by an experienced Movement disorders service \\
During intervention \\
- Inpatient versus outpatient model
\end{tabular}


of experience with device-aided therapies and their beneficial effects [64]. Finally, from both a patient's and health care professional's perspective, potential post-interventional adverse events might represent an additional barrier in choosing device-aided therapies (Table 3). Examples include the greater risk of falling and hallucinations in DBS, potentially leading to longer hospitalization, local nodules at infection site, haemolytic anaemia, fatigue, dizziness, orthostatic hypotension, and electrocardiographic changes in CSAI [65, 66], and the development of polyneuropathy in IJLI treated patients [67]. Related to this, there is limited unbiased and comparable information for all three options, as no randomized controlled trials directly comparing the device-aided therapies have been conducted [59]. However, trials with such comparisons are underway and the results are awaited with great interest [68].

\section{CONCLUSIONS}

In summary, of the device-aided therapies DBS is clearly cost-effective, as these costs are around or below the GDP of the countries where the studies looking at this have been performed. For the infusion therapies this picture is less uniform, although current studies seem to support that long-term use of these latter therapies favours their cost-effectiveness profile. Nonetheless, universally acceptable cost thresholds for device-aided therapies are lacking. Additionally, often indirect, improvement of factors other than motor improvement used as the primary endpoint to determine effectiveness, may justify the use of infusion therapies in PD. Moreover, several studies regarding cost-effectiveness for device-aided therapies in PD with a temporal window of over five years show that the ICER was within, or at least near, the respective countries' GDP per capita, the threshold that remains the prevailing measure of assessing cost-effectiveness for public policy decisions. This suggests that further improvement to the delivery of infusion therapies is likely to make them costeffective in the long-run. Several studies suggest that societal costs and costs associated with care burden with these therapies and other indirect costs, often not taken into account in cost-effectiveness analyses, decrease compared to best medical therapy. Although DBS appears to be the most cost-effective of the three device-aided therapies, caution should be observed when comparing to the infusion therapies. Often the PD patient populations for DBS and infusion therapies differ, as e.g., per DBS inclusion criteria patients with cognitive problems or depression are excluded, but are often, to a certain extent, allowed for patients on infusion therapies. In addition to the recent efforts that have been made to reduce the direct costs of the infusion therapies, other factors need to be taken into account. As most analyses performed to date have only looked at the effectiveness based on motor improvement, future cost-effectiveness analyses should additionally look at non-motor effects and associated improvements in quality of life and reductions in both direct and indirect costs.

\section{ACKNOWLEDGMENTS}

KS acknowledges support from European Academy of Neurology and CoCoCare Program.

\section{CONFLICT OF INTEREST}

No specific funding was received for this work. The authors declare that there are no conflicts of interest relevant to this work.

\section{FINANCIAL DISCLOSURES OF ALL AUTHORS (FOR THE PRECEDING 12 MONTHS)}

KS received a fellowship grant from Department of Neurology, Christian-Albrechts University, Kiel Germany, Research fellowship from European Academy of Neurology.

DvW received a fellowship grant, and consultancy and speaker fees from Britannia Pharmaceuticals, speaker fees from Bial Pharmaceuticals, and consultancy fees from Invisio Pharma.

TP received grants from National Science Centre (Poland), Ministry of Science and Higher Education (Dialogue Program), and Boards: Council of the Polish National Agency of Academic Exchange, Polish National Committee for Ethical Review of Animal Experimentation, Bioethical Committee of the Silesian Medical Chamber, Boethical Committee of the Silesian Medical University, Council of the Kukuczka Academy of Physical Education in Katowice. Financial Fees from SPCG Law Firm (Katowice Branch Office).

AC received scholarship by the Konrad-Adenauer Foundation.

CRB has nothing to disclose. 
PMM has received honoraria from National School of Public Health (ISCIII) and Editorial Viguera for lecturing in courses or publications; from International Parkinson and Movement Disorder Society (IPMDS) for management of the Program on Rating Scales; and from Bial for advice in a clinicalepidemiological study. Grants from the IPMDS for attending the IPMDS International Congress 2019, and for development and validation of the MDSNMS.

PO Advisory board/expert advice: AbbVie, Bial, Britannia, Evolan, Global Kinetics, Kyowa-Kirin, Lobsor, Neuroderm, Nordic Infucare, UCB, Stada, Zambon, PD Neurotechnology

Honoraria for lectures: AbbVie, Bial, KyowaKirin, PD Neurotechnology, Zambon

Grants (Investigator Initiated): AbbVie, Bial, Global Kinetics Academic grants: Swedish Parkinson Academy, Hardebo Foundation, Lund University Medical Faculty, Swedish Parkinson Foundation, Southern Swedish Health Care Region, Skåne University Hospital donations.

KRC received grants (Investigator Initiated) from: Britania Pharmaceuticals, AbbVie, UCB, GKC, Bial, Aacdemic grants: EU, IMI EU, Horizon 2020, Parkinson's UK, NIHR, PDNMG, EU (Horizon 2020), Kirby Laing Foundation, NPF, MRC, Wellcome Trust. Advisory board: AbbVie, UCB, GKC, Bial, Cynapsus, Novartis, Lobsor, Stada, Medtronic, Zambon, Profile, Sunovion, Roche, Therevance, Scion, Britannia. Honoraria for lectures: AbbVie, Britannia, UCB, Mundipharma, Zambon, Novartis, Boeringer Ingelheim.

\section{REFERENCES}

[1] Wirdefeldt K, Adami HO, Cole P, Trichopoulos D, Mandel J (2011) Epidemiology and etiology of Parkinson's disease: A review of the evidence. Eur J Epidemiol 26(Suppl 1), S1-58.

[2] Heald AH, Livingston M, Stedman M, Wyrko Z (2016) Higher levels of apomorphine and rotigotine prescribing reduce overall secondary healthcare costs in Parkinson's disease. Int J Clin Pract 70, 907-915.

[3] Dorsey ER, Bloem BR (2018) The Parkinson pandemic-a call to action. JAMA Neurol 75, 9-10.

[4] Rascol O, Goetz C, Koller W, Poewe W, Sampaio C (2002) Treatment interventions for Parkinson's disease: An evidence based assessment. Lancet 359, 1589-1598.

[5] Antonini A, Moro E, Godeiro C, Reichmann H (2018) Medical and surgical management of advanced Parkinson's disease. Mov Disord 33, 900-908.

[6] Antonini A, Stoessl AJ, Kleinman LS, Skalicky AM, Marshall TS, Sail KR, Onuk K, Odin PLA (2018) Developing consensus among movement disorder specialists on clinical indicators for identification and management of advanced Parkinson's disease: A multi-country Delphipanel approach. Curr Med Res Opin 34, 2063-2073.

[7] Storch A, Schneider CB, Wolz M, Sturwald Y, Nebe A, Odin P, Mahler A, Fuchs G, Jost WH, Chaudhuri KR, Koch R, Reichmann H, Ebersbach G (2013) Nonmotor fluctuations in Parkinson disease: Severity and correlation with motor complications. Neurology 80, 800-809.

[8] van Wamelen DJ, Grigoriou S, Chaudhuri KR, Odin P (2018) Continuous drug delivery aiming continuous dopaminergic stimulation in Parkinson's disease. J Parkinsons Dis 8, S65-s72.

[9] Dafsari HS, Martinez-Martin P, Rizos A, Trost M, Dos Santos Ghilardi MG, Reddy P, Sauerbier A, Petry-Schmelzer JN, Kramberger M, Borgemeester RWK, Barbe MT, Ashkan K, Silverdale M, Evans J, Odin P, Fonoff ET, Fink GR, Henriksen T, Ebersbach G, Pirtosek Z, Visser-Vandewalle V, Antonini A, Timmermann L, Ray Chaudhuri K (2019) EuroInf 2: Subthalamic stimulation, apomorphine, and levodopa infusion in Parkinson's disease. Mov Disord 34, 353-365.

[10] Martinez-Martin P, Reddy P, Katzenschlager R, Antonini A, Todorova A, Odin P, Henriksen T, Martin A, Calandrella D, Rizos A, Bryndum N, Glad A, Dafsari HS, Timmermann L, Ebersbach G, Kramberger MG, Samuel M, Wenzel K, Tomantschger V, Storch A, Reichmann H, Pirtosek Z, Trost M, Svenningsson P, Palhagen S, Volkmann J, Chaudhuri KR (2015) EuroInf: A multicenter comparative observational study of apomorphine and levodopa infusion in Parkinson's disease. Mov Disord 30, 510-516.

[11] Benabid AL, Pollak P, Hommel M, Gaio JM, de Rougemont J, Perret J (1989) [Treatment of Parkinson tremor by chronic stimulation of the ventral intermediate nucleus of the thalamus]. Rev Neurol (Paris) 145, 320-323.

[12] Dafsari HS, Silverdale M, Strack M, Rizos A, Ashkan K, Mahlstedt P, Sachse L, Steffen J, Dembek TA, VisserVandewalle V, Evans J, Antonini A, Martinez-Martin P, Ray-Chaudhuri K, Timmermann L (2018) Nonmotor symptoms evolution during 24 months of bilateral subthalamic stimulation in Parkinson's disease. Mov Disord 33, 421-430.

[13] Dafsari HS, Reddy P, Herchenbach C, Wawro S, PetrySchmelzer JN, Visser-Vandewalle V, Rizos A, Silverdale M, Ashkan K, Samuel M, Evans J, Huber CA, Fink GR, Antonini A, Chaudhuri KR, Martinez-Martin P, Timmermann L (2016) Beneficial effects of bilateral subthalamic stimulation on non-motor symptoms in Parkinson's disease. Brain Stimul 9, 78-85.

[14] Poewe W, Mahlknecht P (2020) Pharmacologic treatment of motor symptoms associated with Parkinson disease. Neurol Clin 38, 255-267.

[15] Liberati A, Altman DG, Tetzlaff J, Mulrow C, Gotzsche PC, Ioannidis JP, Clarke M, Devereaux PJ, Kleijnen J, Moher D (2009) The PRISMA statement for reporting systematic reviews and meta-analyses of studies that evaluate health care interventions: Explanation and elaboration. J Clin Epidemiol 62, e1-34.

[16] Kamusheva MS, Gerasimov N, Petrova GI (2013) Intestinal gel Levodopa+Carbidopa in Parkinson's patients with frequent and prolonged akinesia-an economic evaluation. Int J Pharm Sci Rev Res 22, 244-246.

[17] Organisation for Economic Co-operation and Development. http://www.oecd.org/

[18] Kristiansen IS, Bingefors K, Nyholm D, Isacson D (2009) Short-term cost and health consequences of duodenal levodopa infusion in advanced Parkinson's disease in Sweden: 
An exploratory study. Appl Health Econ Health Policy 7, 167-180.

[19] Willis M, Persson U, Zoellner Y, Gradl B (2010) Reducing uncertainty in value-based pricing using evidence development agreements: The case of continuous intraduodenal infusion of levodopa/carbidopa (Duodopa(R)) in Sweden. Appl Health Econ Health Policy 8, 377-386.

[20] Palhagen SE, Sydow O, Johansson A, Nyholm D, Holmberg B, Widner H, Dizdar N, Linder J, Hauge T, Jansson R, Bergmann L, Kjellander S, Marshall TS (2016) Levodopacarbidopa intestinal gel (LCIG) treatment in routine care of patients with advanced Parkinson's disease: An open-label prospective observational study of effectiveness, tolerability and healthcare costs. Parkinsonism Relat Disord 29, 17-23.

[21] Lowin J, Sail K, Baj R, Jalundhwala YJ, Marshall TS, Konwea H, Chaudhuri KR (2017) The cost-effectiveness of levodopa/carbidopa intestinal gel compared to standard care in advanced Parkinson's disease. J Med Econ 20, 1207 1215.

[22] Lowin J, Bergman A, Chaudhuri KR, Findley LJ, Roeder C, Schifflers M, Wood E, Morris S (2011) A cost-effectiveness analysis of levodopa/carbidopa intestinal gel compared to standard care in late stage Parkinson's disease in the UK. $J$ Med Econ 14, 584-593.

[23] Lundqvist C, Beiske AG, Reiertsen O, Kristiansen IS (2014) Real life cost and quality of life associated with continuous intraduodenal levodopa infusion compared with oral treatment in Parkinson patients. J Neurol 261, 2438-2445.

[24] Walter E, Odin P (2015) Cost-effectiveness of continuous subcutaneous apomorphine in the treatment of Parkinson's disease in the UK and Germany. J Med Econ 18, 155-165.

[25] Vivancos-Matellano F, Garcia-Ruiz AJ, Garcia-Agua Soler N (2016) [Pharmacoeconomic study of the treatment of advanced Parkinson's disease]. Rev Neurol 63, 529-536.

[26] Kalabina S, Belsey J, Pivonka D, Mohamed B, Thomas C, Paterson B (2019) Cost-utility analysis of levodopa carbidopa intestinal gel (Duodopa) in the treatment of advanced Parkinson's disease in patients in Scotland and Wales. J Med Econ 22, 215-225.

[27] Valldeoriola F, Morsi O, Tolosa E, Rumia J, Marti MJ, Martinez-Martin P (2007) Prospective comparative study on cost-effectiveness of subthalamic stimulation and best medical treatment in advanced Parkinson's disease. Mov Disord 22, 2183-2191.

[28] Fundament T, Eldridge PR, Green AL, Whone AL, Taylor RS, Williams AC, Schuepbach WM (2016) Deep brain stimulation for Parkinson's disease with early motor complications: A UK cost-effectiveness analysis. PLoS One 11, e0159340.

[29] Zhu XL, Chan DT, Lau CK, Poon WS, Mok VC, Chan AY, Wong LK, Yeung JH, Leung MC, Tang VY, Wong RK, Yeung C (2014) Cost-effectiveness of subthalmic nucleus deep brain stimulation for the treatment of advanced Parkinson disease in Hong Kong: A prospective study. World Neurosurg 82, 987-993.

[30] McIntosh E, Gray A, Daniels J, Gill S, Ives N, Jenkinson C, Mitchell R, Pall H, Patel S, Quinn N, Rick C, Wheatley K, Williams A (2016) Cost-utility analysis of deep brain stimulation surgery plus best medical therapy versus best medical therapy in patients with Parkinson's: Economic evaluation alongside the PD SURG trial. Mov Disord 31, 1173-1182.
[31] Eggington S, Valldeoriola F, Chaudhuri KR, Ashkan K, Annoni E, Deuschl G (2014) The cost-effectiveness of deep brain stimulation in combination with best medical therapy, versus best medical therapy alone, in advanced Parkinson's disease. J Neurol 261, 106-116.

[32] Valldeoriola F, Puig-Junoy J, Puig-Peiro R (2013) Cost analysis of the treatments for patients with advanced Parkinson's disease: SCOPE study. J Med Econ 16, 191-201.

[33] deSouza RM, Moro E, Lang AE, Schapira AH (2013) Timing of deep brain stimulation in Parkinson disease: A need for reappraisal? Ann Neurol 73, 565-575.

[34] Dams J, Siebert U, Bornschein B, Volkmann J, Deuschl G, Oertel WH, Dodel R, Reese JP (2013) Cost-effectiveness of deep brain stimulation in patients with Parkinson's disease. Mov Disord 28, 763-771.

[35] Tomaszewski KJ, Holloway RG (2001) Deep brain stimulation in the treatment of Parkinson's disease: A costeffectiveness analysis. Neurology 57, 663-671.

[36] Dams J, Balzer-Geldsetzer M, Siebert U, Deuschl G, Schuepbach WM, Krack P, Timmermann L, Schnitzler A, Reese JP, Dodel R (2016) Cost-effectiveness of neurostimulation in Parkinson's disease with early motor complications. Mov Disord 31, 1183-1191.

[37] Pietzsch JB, Garner AM, Marks WJ, Jr. (2016) Costeffectiveness of deep brain stimulation for advanced Parkinson's disease in the United States. Neuromodulation 19, 689-697.

[38] Spottke EA, Volkmann J, Lorenz D, Krack P, Smala AM, Sturm V, Gerstner A, Berger K, Hellwig D, Deuschl G, Freund HJ, Oertel WH, Dodel RC (2002) Evaluation of healthcare utilization and health status of patients with Parkinson's disease treated with deep brain stimulation of the subthalamic nucleus. J Neurol 249, 759-766.

[39] von Campenhausen S, Winter Y, Rodrigues e Silva A, Sampaio C, Ruzicka E, Barone P, Poewe W, Guekht A, Mateus C, Pfeiffer KP, Berger K, Skoupa J, Bötzel K, Geiger-Gritsch S, Siebert U, Balzer-Geldsetzer M, Oertel WH, Dodel R, Reese JP (2011) Costs of illness and care in Parkinson's disease: An evaluation in six countries. Eur Neuropsychopharmacol 21, 180-191.

[40] Espay AJ, Vaughan JE, Marras C, Fowler R, Eckman MH (2010) Early versus delayed bilateral subthalamic deep brain stimulation for parkinson's disease: A decision analysis. Mov Disord 25, 1456-1463.

[41] Walleser AS, Eggington S, Valyi A (2014) PND27 - Cost comparison of deep drain stimulation (DBS) and continued subcutaneous apomorphine infusion (CSAI) in patients with advanced Parkinson's disease. Value Health 17, A395.

[42] Rizzi M, Messina G, Penner F, D’Ammando A, Muratorio F, Franzini A (2015) Internal pulse generators in deep brain stimulation: Rechargeable or not? World Neurosurg 84, 1020-1029.

[43] Perez J, Gonzalez V, Cif L, Cyprien F, Chan-Seng E, Coubes P (2017) Rechargeable or Nonrechargeable Deep Brain Stimulation in Dystonia: A Cost Analysis. Neuromodulation 20, 243-247.

[44] Senek M, Nielsen EI, Nyholm D (2017) Levodopaentacapone-carbidopa intestinal gel in Parkinson's disease: A randomized crossover study. Mov Disord 32, 283-286.

[45] https://www.apoteket.dk/

[46] Leta V, van Wamelen DJ, Sauerbier A, Jones S, Parry M, Rizos A, Chaudhuri KR (2020) Opicapone and levodopacarbidopa intestinal gel infusion: The way forward towards 
cost savings for the healthcare systems? J Parkinsons Dis 10, 1535-1539.

[47] Rodríguez-Blázquez C, Forjaz MJ, Lizán L, Paz S, Martínez-Martín P (2015) Estimating the direct and indirect costs associated with Parkinson's disease. Expert Rev Pharmacoecon Outcomes Res 15, 889-911.

[48] McCrone P, Allcock LM, Burn DJ (2007) Predicting the cost of Parkinson's disease. Mov Disord 22, 804-812.

[49] National Institute for Health and Care Excellence. https://www.nice.org.uk/about/what-we-do/ourprogrammes/nice-guidance/nice-technology-appraisalguidance/process

[50] Cameron D, Ubels J, Norström F (2018) On what basis are medical cost-effectiveness thresholds set? Clashing opinions and an absence of data: A systematic review. Glob Health Action 11, 1447828.

[51] Laupacis A, Feeny D, Detsky AS, Tugwell PX (1992) How attractive does a new technology have to be to warrant adoption and utilization? Tentative guidelines for using clinical and economic evaluations. CMAJ 146, 473-481.

[52] World Health Organization. Economic evaluation \& analysis (WHO-CHOICE). https://www.who.int/choice/en/.

[53] World Health Organization. Thresholds for the cost-effectiveness of interventions: Alternative approaches. https://www.who.int/bulletin/volumes/93/2/14-138206/en/

[54] Charlton V, Rid A (2019) Innovation as a value in healthcare priority-setting: The UK experience. Soc Justice Res 32, 208-238.

[55] Findley LJ, Wood E, Lowin J, Roeder C, Bergman A, Schifflers M (2011) The economic burden of advanced Parkinson's disease: An analysis of a UK patient dataset. J Med Econ 14, 130-139.

[56] Schapira AHV, Chaudhuri KR, Jenner P (2017) Non-motor features of Parkinson disease. Nat Rev Neurosci 18, 435450.

[57] Ray Chaudhuri K, Antonini A, Robieson WZ, SanchezSolino O, Bergmann L, Poewe W (2019) Burden of non-motor symptoms in Parkinson's disease patients predicts improvement in quality of life during treatment with levodopa-carbidopa intestinal gel. Eur J Neurol 26, 581e543.

[58] Massano J, Garrett C (2012) Deep brain stimulation and cognitive decline in Parkinson's disease: A clinical review. Front Neurol 3, 66-66.

[59] Nijhuis FAP, van den Heuvel L, Bloem BR, Post B, Meinders MJ (2019) The patient's perspective on shared decision-making in advanced Parkinson's disease: A crosssectional survey study. Front Neurol 10, 896.

[60] van der Eijk M, Faber MJ, Al Shamma S, Munneke M, Bloem BR (2011) Moving towards patient-centered healthcare for patients with Parkinson's disease. Parkinsonism Relat Disord 17, 360-364.

[61] Munhoz RP, Picillo M, Fox SH, Bruno V, Panisset M, Honey CR, Fasano A (2016) Eligibility criteria for deep brain stimulation in Parkinson's disease, tremor, and dystonia. Can J Neurol Sci 43, 462-471.

[62] Nijhuis FA, van Heek J, Bloem BR, Post B, Faber MJ (2016) Choosing an advanced therapy in Parkinson's disease;
Is it an evidence-based decision in current practice? $J$ Parkinsons Dis 6, 533-543.

[63] Dorsey ER, Vlaanderen FP, Engelen LJ, Kieburtz K, Zhu W, Biglan KM, Faber MJ, Bloem BR (2016) Moving Parkinson care to the home. Mov Disord 31, 1258-1262.

[64] Volkmann J, Albanese A, Antonini A, Chaudhuri KR, Clarke CE, de Bie RM, Deuschl G, Eggert K, Houeto JL, Kulisevsky J, Nyholm D, Odin P, Ostergaard K, Poewe W, Pollak P, Rabey JM, Rascol O, Ruzicka E, Samuel M, Speelman H, Sydow O, Valldeoriola F, van der Linden C, Oertel W (2013) Selecting deep brain stimulation or infusion therapies in advanced Parkinson's disease: An evidence-based review. J Neurol 260, 2701-2714.

[65] Vijiaratnam N, Sue CM (2018) Levodopa-carbidopa intestinal gel: 'dismantling the road blocks of a journey'. Intern Med J 48, 472-474.

[66] Pessoa RR, Moro A, Munhoz RP, Teive HAG, Lees AJ (2018) Apomorphine in the treatment of Parkinson's disease: A review. Arq Neuropsiquiatr 76, 840-848.

[67] Nyholm D (2012) Duodopa ${ }^{\circledR}$ treatment for advanced Parkinson's disease: A review of efficacy and safety. Parkinsonism Relat Disord 18, 916-929.

[68] van Poppelen D, Sisodia V, de Haan R, Dijkgraaf M, Schuurman P, Geurtsen G, Berk A, de Bie R, Dijk J (2020) Protocol of a randomized open label multicentre trial comparing continuous intrajejunal levodopa infusion with deep brain stimulation in Parkinson's disease-the INfusion VErsus STimulation (INVEST) study. BMC Neurol 20, 1-9.

[69] Gerzeli S, Cavallo M, Caprari F, Ponzi P, Gruppo di Studio D (2002) Analysis of deep brain stimulation (DBS) costs: An observational study on Italian patients. Pharmacoeconomics Ital Res Articles 4, 66-79.

[70] Meissner W, Schreiter D, Volkmann J, Trottenberg T, Schneider GH, Sturm V, Deuschl G, Kupsch A (2005) Deep brain stimulation in late stage Parkinson's disease: A retrospective cost analysis in Germany. J Neurol 252, 218-223.

[71] Kawamoto Y, Mouri M, Taira T, Iseki H, Masamune K (2016) Cost-effectiveness analysis of deep brain stimulation in patients with Parkinson's disease in Japan. World Neurosurg 89, 628-635.e621.

[72] Odin P, Ray Chaudhuri K, Slevin JT, Volkmann J, Dietrichs E, Martinez-Martin P, Krauss JK, Henriksen T, Katzenschlager R, Antonini A, Rascol O, Poewe W; National Steering Committees (2015) Collective physician perspectives on non-oral medication approaches for the management of clinically relevant unresolved issues in Parkinson's disease: Consensus from an international survey and discussion program. Parkinsonism Relat Disord 21, 1133-1144.

[73] Vijiaratnam N, Sue CM (2018) Levodopa-carbidopa intestinal gel: 'dismantling the road blocks of a journey'. Intern Med J 48, 472-474.

[74] Umemura A, Oyama G, Shimo Y, Nakajima M, Nakajima A, Jo T, Sekimoto S, Ito M, Mitsuhashi T, Hattori N, Arai H (2016) Current topics in deep brain stimulation for Parkinson disease. Neurol Med Chir (Tokyo) 56, 613-625. 